\title{
JUST WAR THEORY
}




\title{
JUST WAR THEORY
}

\section{A REAPPRAISAL}

\author{
Edited by \\ Mark Evans
}

Edinburgh University Press 
(C) in selection and editorial matter, Mark Evans 2005

(C) in the individual contributions is retained by the authors

Edinburgh University Press Ltd

22 George Square, Edinburgh

Typeset in Palatino Light by

Koinonia, Manchester, and

printed and bound in Great Britain by

MPG Books Ltd, Bodmin, Cornwall

A CIP record for this book is available from the

British Library

ISBN 0748620745 (hardback)

ISBN 0748620753 (paperback)

The right of the contributors to be identified as authors of this work has been asserted in accordance with the Copyright, Designs and Patents Act 1988. 